
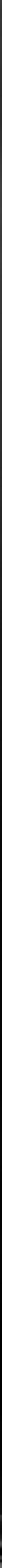

Nina Callaghan, Rabyn Foley and Mark Swilling (EDITuRS) 


\section{A CAPTURED SECURITY CLUSTER}

Marianne Thamm

\subsection{STATE SECURITY ASSAULT}

If the intelligence and security services of a country mirror its government, then the South African government between 2009 and 2018 - the nine years Jacob Gedleyihlekisa Zuma served as president - resembles a mafia, accountable to no one but the President himself.

This is the essence of the damning findings of a 141-page High-Level Panel Review into the State Security Agency (SSA) commissioned by President Cyril Ramaphosa in June 2018 (High-Level Review Panel on the SSA, 2018). Ramaphosa requested the review four months after Zuma had been forced to resign as President of the country on Valentine's Day amid mounting piles of evidence of industrial-scale fraud, corruption and the capture of the state on his watch. The redacted findings of the High-Level panel were publicly released in March 2019, putting an end to over a decade of official secrecy, the mothballing of earlier investigations into malfeasance in the security cluster and cover-ups by Zuma loyalists of the widespread criminalisation and politicisation of the security cluster.

An investigation into the SSA, ordered in 2009 by then Minister of State Security, Siyabonga Cwele, as well a 2013/14 investigation into the National Intelligence Agency (before it morphed into the SSA) Principle Agent Network (PAN) by InspectorGeneral of Intelligence (IGI), Faith Radebe, had both unearthed proof of fraud, corruption and the abuse of state resources (Merten, 2017; Maughan, 2018). From 2009 onwards, two Ministers of State Security, Siyabonga Cwele, and his successor, David Mahlobo, would have been aware of the clear and present danger illegal SSA operations presented to South Africa's democratic state.

But perhaps it was not the state that they were concerned with protecting.

The 2009 internal investigation into the SSA found that Arthur Fraser, then Deputy Director General of the National Intelligence Agency (NIA) who also headed PAN, was one of 15 people against whom there was "sufficient proof to institute criminal 
investigations" (Merten, 2017; Maughan, 2018). "It appeared to the panel that there had been instances of serious criminal behaviour, which had taken place under the guise of conducting covert work and that this behaviour may have involved theft, forgery and uttering, fraud, corruption and even bordered on transgressions of the Prevention of Organised Crime Act", the SSA investigation found (Etheridge, 2019). Fraser left the SSA in January 2010 and the IGI and SSA reports were left to gather dust.

PAN was disbanded in 2011 having blown an unaccounted for budget of around R1bn in three years according to investigative journalist Jacques Pauw's The President's Keepers (Pauw, 2017).This claim by Pauw was later verified in a 2014 Report by the Office of the Inspector General of Intelligence (OIGI), Faith Radebe, to the Minister of State Security, Siyabonga Cwele and titled OIGI investigation into The Principal Agent Network (PAN) Programme of the NIA. ${ }^{1}$ Cwele had instructed Radebe on 20 June 2013 to conduct the investigation into the PAN Programme of the NIA.

Fraser, a seasoned intelligence operative, has been named as the spy who leaked illegal NIA phone taps of the then Directorate of Special Operations - the Scorpions - who had investigated high-profile ANC officials, including Zuma and his financial adviser Shabir Shaik, between 2001 and 2009 before it was defanged (Mail \& Guardian, 2009). The "spy tapes" were later leveraged by the NPA to drop the corruption prosecution of Zuma on the eve of the 2009 elections. At its 52nd Elective Conference in Polokwane in 2007, the ANC resolved to disband the Directorate of Special Operations, also known as the Scorpions. The independent, multi-disciplinary agency was replaced with the Directorate for Priority Crime Investigation (DPCI), also known as the Hawks. This agency falls under SAPS, diluting its independence considerably.

It was at the same Polokwane conference that Jacob Zuma trounced then State and Party President, Thabo Mbeki who was running for a third term. Zuma's path to power and dominance in the party had been prepared and swept clean.

Having left the SSA in 2010, Arthur Fraser was back in the official loop in 2016, having been appointed by Mahlobo as the Director General (DG) of the SSA. The appointment came despite accusations of impropriety in the OIGI investigations and a trail of dodgy deals, as uncovered following an investigation by former Public Protector, Thuli Madonsela, detailed in her 2015 report Derailed (Public Protector, 2015). Fraser's time away from government employment had proved highly lucrative. In the gap between running PAN and his reappointment as DG of the SSA, Fraser had co-founded a security company, Resurgent Risk Managers, with former NIA head, Manala Manzini. In 2014, the South African Social Security Agency (SASSA) forked the author. 
out R14.3m to Resurgent for "consultancy services". A year later, the Passenger Rail Agency (Prasa), with Lucky Montana as CEO, awarded a R90m security contract to Resurgent. A 2017 Treasury probe into the Prasa Resurgent tender found that Fraser's company had submitted a fake tax certificate in the bid (\#UniteBehind, 2017; Van Wyk, 2017). Nothing has come of it.

Back in 2010, after the internal SSA investigation, Cwele at first appeared to have had an appetite to hold those implicated, including Fraser, to account. His intentions to refer the matter to the NPA as well as request assistance from the DPCI and the SIU also came to nought.

\subsection{RED FLAGS AND SMOKE SCREENS}

Two years into Zuma's term of office, in 2011, a potential "national security threat" - the relationship between the Gupta family, the President, members of the Zuma family as well as other high-profile governing-party politicians - was red-flagged by Zuma's three newly-appointed intelligence bosses. Moe Shaik, Zuma’s Foreign Intelligence Head, Jeff Maqetuka, DG of State Security and Gibson Njenje, Head of the SSA's domestic branch, had investigated the Gupta family's apparent growing influence and had been concerned at "how they conducted themselves" (Letsoala \& Molele, 2013). It subsequently emerged that the intelligence heads had been aware of the Gupta family's influence in Zuma's first cabinet reshuffle in October 2010. By then Zuma was regularly visiting the Gupta "compound" in Saxonwold, according to Njenje (Njenje, 2018; Zondo Commission, 2019).

All three former heads of SSA have testified at the Zondo Commission of Inquiry into State Capture, setting out how they had investigated the Gupta family and their influence, and the resistance they faced in this undertaking. The Commission is ongoing, and their evidence has yet to be tested.

In 2011, Cwele dismissed the investigation by the intelligence heads as "improper" before shutting it down, leading to the swift exit of Shaik, Maqetuka and Njenje who all resigned a short while later. Tensions between the Minister and the trio had already been simmering due to Cwele's "unauthorised" surveillance of Cabinet Ministers (News24, 2011; SAPA, 2011).

In 2014, Cwele was shuffled out of cabinet and replaced with the then little-known Mpumalanga biochemist David Mahlobo. Cwele's wife, Sheryl, had been convicted in 2011 of drug trafficking and had been sentenced to a 12-year jail term. The Minister had claimed that he had been unaware of his wife's criminal sideline. Maqetuka has testified to the discomfort he had with SSA personnel being assigned to accompanying 
Cwele's wife during her trial - an abuse of power that added to tensions between the DG and the Minister (Zondo Commission, 2020c).

Cwele's canning of the investigation into the Gupta family's proximity to the President and Fraser's seeming impunity in the face of serious allegations, are examples of what the High-Level panel described as a "serious politicisation and factionalisation" of the intelligence services which had been perverted "into a private resource to serve the political and personal interests of particular individuals" (High-Level Review Panel on the SSA, 2018, p. ii).

It is likely that Zuma's own role in the ANC's intelligence structures in exile shaped and solidified his notion of power, control, paranoia and influence. It is, however, clear he deployed these skills long before being elected president of the ANC and the country. Zuma's grip on the intelligence services was consolidated almost immediately in 2009 when his incoming administration undertook to reverse the vision and values of the 1994 White Paper on Intelligence (adopted by parliament in 2005). By amalgamating (through a proclamation and not a parliamentary process), the country's intelligence services - the NIA, the South African Secret Service and the South African National Academy and National Communications Centre - Zuma centralised operations into the State Security Agency replicating apartheid era structures (High-Level Review Panel on the SSA, 2018; Shaik, 2019). Zuma, as the president, thus consolidated his control over the intelligence services.

With a history of apartheid, government abuse of the intelligence services against the country's citizens and in service to an undemocratic state, the authors of the White Paper sought to provide a policy framework for the "principles and functioning of the intelligence services in a democratic South Africa" (High-Level Review Panel on the SSA, 2018, p. 18). The White Paper set out the establishment of two separate civilian intelligence services - domestic (the South African Secret Services - SASS) and external (National Intelligence Agency - NIA) (Republic of South Africa, 1995). However, a Presidential Proclamation on 11 September 2009 collapsed the SASS and NIA into the State Security Agency (SSA). This was followed by the centralisation of command and control of civilian intelligence (High-Level Review Panel on the SSA, 2018).

With an absence of a clear legislative framework to guide this integration process, the scene was set for a reorientation of the intelligence services from "human security" to a narrow "state security orientation", the panel found. The panel noted that from 2009, there had been a "marked doctrinal shift" in the intelligence services away from the prescripts of the Constitution. It also noted that the amalgamation of NIA and the SASS into the SSA "did not achieve its purported objectives and was 
contrary to existing policy". The SSA's unaccountable access to cash as well as the "disproportionate application of secrecy in the SSA" (High-Level Review Panel on the SSA, 2018, p. 2) created the perfect environment for Jacob Zuma's stealthy and steady grip on the levers of state power.

\subsection{BY HOOK OR BY CROOK: REMOVING OBSTRUCTIONISTS}

Zuma ascended the Office of the Presidency a marked man with the Arms Deal charges dangling like a sword of Damocles over his entire term of office. The profligate President's chaotic tax matters, too, snagged the attention of SARS, which had tried discreetly for several years, albeit unsuccessfully, to assist the President to "get his house in order" (see Chapter 15). Zuma's "Stalingrad strategy" aimed at keeping him out of court and enabling his encroachment on the independence of the state, began to play out in full public and parliamentary view. Most importantly Zuma needed to shift loyalists, whether qualified or not, into key positions where they could watch his back (Bhorat, Buthelezi, Chipkin, Duma, Mondi, Peter, Qobo, Swilling \& Friedenstein, 2017). This included the powerful Office of the Inspector-General of Intelligence, the SSA, SAPS Crime Intelligence, the NPA and the Public Protector.

As the reality of the impending disaster of the Zuma administration began to dawn on ethical officials across government departments and they began to push-back, those beholden to the President deployed any means necessary to neutralise threats. Corruption-busting officials across ministries, law enforcement services, government departments and Chapter 9 institutions who were singled out as obstacles, were systematically targeted and hounded out of office.

Orchestrating these attacks, covert SSA agents embarked on "black ops" campaigns, including but not confined to planting stories in the mainstream media to discredit individuals. The Sunday Times "rogue unit" narrative which unfolded in 2014 is a case in point (Siqoko, 2018). The newspaper, after being taken to the ombudsman, offered an apology and later withdrew all articles which had sensationally claimed that the perfectly legal SARS High Risk Investigative Unit had been illegally established, had run a brothel and had spied on Jacob Zuma, high profile political figures, including opposition parties, members of the tobacco industry, as well as other politically connected business persons and tax evaders (see Chapter 11).

As the country headed for peak state capture around 2014, a network of deep state SSA agents was deployed to key departments, including SARS, the Passenger Rail Agency of South Africa (PRASA), electricity supplier Eskom, Transnet, South African Airways (SAA) and other government departments to act as Zuma's eyes and ears. In a conversation with Public Protector Busisiswe Mkhwebane in January 2019, current 
Inspector-General for Intelligence, Setlhomamaru Dintwe, and his legal adviser, Advocate Jay Govender, admitted as much, adding that at least 186 of these SSA "sleeper" agents who were being paid "off the books" were still active (Thamm, 2019a).

The IGI has since resolved to reinvestigate around 60 complaints relating to covert and illegal SSA activities during the Zuma presidency, including that one agent placed at SARS had run a network of 21 agents in the tax agency. Her deep undercover work coincided with the attack on SARS, the construction of the "rogue unit" narrative and the ultimate purging and hounding by the DPCI of former SARS Commissioner, Pravin Gordhan, as well as the entire SARS executive after Zuma's appointment of Tom Moyane as SARS commissioner in 2014 (see Chapters 11 and 15).

Media reports that SSA agents were attacking SARS in order to hobble investigations prompted Mahlobo in 2014 to task then Inspector-General (IG), Faith Radebe, with an investigation into the SSA (OIGI, 2014). The result was a Report by Radebe which has since been declared by the North Gauteng High Court to be invalid and set aside. The ruling was made by Judge Sulet Potterill in June 2020 (Cowan, 2020a).

Radebe, while she had no mandate over SARS, found that an illegal investigative unit had been established in SARS and that commissioner at the time, Pravin Gordhan, should be charged (OIGI, 2014). Radebe based her findings on testimony given by SSA agents, including one of the most notorious, Thulani "Silence" Dlomo, known as "Zuma's spy" and head of the rogue SSA Special Operations Unit (Hunter, 2019). Dlomo was significantly implicated in the High Level Panel Review report (2018).

While Radebe's report remained classified, there were ongoing attempts by the Public Protector, Busisiwe Mkhwebane, herself a former SSA employee, to access these findings against Gordhan (Pheto, 2020; Thamm, 2020).

A pattern soon emerged in the onslaught against officials viewed as an obstruction to Zuma and his loyalists. This included the weaponisation of disciplinary proceedings coupled with reports commissioned from private legal and accounting firms (paid for by tax money) to arrive at tailor-made findings. These would then be used to formulate and justify trumped-up charges by the DPCI, SAPS and the NPA, all combined to exact maximum damage on state institutions and individuals seeking to protect these from predatory insider attacks (see Chapters 11, 13 and 15).

Those hand-picked to head the DPCI, the SAPS (as well as Crime Intelligence) and the NPA during this period were all Zuma loyalists. They include Hawks head Berning Ntlemeza, Crime Intelligence head Richard Mdluli, as well as NPA Heads at various times, Nomcgobo Jiba and Shaun Abrahams. 
The targeted officials include former Ministers of Finance, Pravin Gordhan and Nhlanhla Nene, as well as Deputy Minister of Finance, Mcebisi Jonas. The body count also includes former SARS Deputy Commissioner, Ivan Pillay; the SARS Executive which reported to him; NPA Head, Mxolisi Nxasana; DPCI Head, Anwar Dramat; Gauteng DPCI Head, Shadrack Sibiya; KZN DPCI Head, Johan Booysen; Independent Police Investigative Directorate Executive Director, Robert McBride and NPA prosecutor, Glynnis Breytenbach.

In the costly long run, all of those officials targeted for their anti-corruption work, supported by civil society organisations such as the Helen Suzman Foundation (HSF) and Freedom Under Law (FUL), were vindicated by the country's courts, the one cog in the security cluster that remained relatively uncaptured during the Zuma years. Zuma's attack and attempt to capture the democratic state could not have succeeded without this direct and indirect control and command of key institutions, particularly in the security cluster.

\subsection{A WEB OF ROGUE SPIES}

South Africa's security cluster is a sprawling catchment, drawing 11 ministries and departments into its orbit. Its stated aim, at least according to government itself, is to foster an "integrated approach to governance which is aimed at improving planning, decision-making and service delivery" (South African Government, 2019). The cluster includes the Ministries of Justice and Correctional Services; Defence and Military Veterans; Finance; Home Affairs; Police and State Security. In the over decade-long erosion of accountability and transparency, four institutions - the SSA which falls under the Ministry of State Security, the NPA which falls under the Ministry of Justice and Correctional Services, and the DPCI and SAPS (Crime Intelligence) under the Ministry of Police - were to prove the most effective in dealing with threats to Zuma and his political faction.

Key to Zuma's ability to have eyes and ears everywhere was the SSA's Special Operations Unit (SOU), a parallel intelligence structure headed by Dlomo. The panel found that the SOU, under Dlomo's watch, "was a law unto itself and directly served the political interests of the Executive ... It also undertook intelligence operations which were clearly unconstitutional and illegal" (High-Level Review Panel on the SSA, 2018 , p. 65). These included the training of undercover agents in VIP protection and assigning these to Zuma, as well as others "who were not entitled to such protection" (High-Level Review Panel on the SSA, 2018, p. 65). Dudu Myeni, former SAA Board Chair, Nomgcobo Jiba, former National Director of Public Prosecutions, Collen Maine, former ANCYL President and Berning Ntlemeza, former acting Head of the 
Hawks, were all provided with protection by SSA agents. The VIP protection mandate falls under the SAPS and not the SSA. A member of SSA has testified how the mandate for the SOU changed in 2012 to specifically support Zuma and his friends. Witness $\mathrm{Y}$ (testifying in camera) outlined in detail the VIP services provided to Myeni, highlighting the level of paranoia that prevailed at the time (Zondo Commission, 2020a, 2020b). The evidence is yet to be tested.

Dlomo was appointed Head of the SOU in 2012 under mysterious circumstances. Before this he had been head of security for the KZN department of social development but resigned when a forensic investigation revealed he had received $\mathrm{R} 1 \mathrm{~m}$ in kickbacks for tenders worth R45m awarded by the department (Basson, 2019). In 2020, the matter was still "pending" (Van Diemen, 2019). That Dlomo, who was later appointed Head of Counter Intelligence at the SSA's domestic intelligence branch, enjoyed high-level protection is evidenced by the fact that he was never prosecuted for receiving the alleged kickbacks.

In 2012, it was Dlomo who dispatched apartheid-era spy, Riaan Stander, to Europe on a mission to recover any evidence German arms manufacturer, Ferostaal, might have had on bribes Jacob Zuma or other senior officials allegedly accepted to ensure a smooth passage of the 1999 Arms Deal (Myburgh \& Tau, 2016; Basson, 2019). Stander later instituted a damages claim against the SSA - settled out of court - which is where Dlomo's role in alleged sweeping of evidence for Zuma came to light. Dlomo's unit, the panel found, had also infiltrated and influenced "the media" in an attempt "to counter bad publicity for the country, the then president and the SSA" (High-Level Review Panel on the SSA, 2018, p. 65).

The SOU had also in 2014 set up, at the behest of President Zuma, a bogus union, the Workers Association Union, to spy on the Association of Mineworkers and Construction Union (Amcu) at the Lonmin mine in Marikana (Myburgh, 2016). The SOU had also surveilled civil society organisations and infiltrated the \#FeesMustFall protests "to influence the direction of the student movement" (High-Level Review Panel on the SSA, 2018, p. 65).

In its findings, the High-Level panel found the manipulation of the SSA had emerged "from the top - the Presidency - through the Ministry of State Security and into the management and staff of the SSA" (High-Level Review Panel on the SSA, 2018, p. 69).

The activities of the SSA including "attempts at social engineering, through its SO arm, and the involvement of the President and the Minister [David Mahlobo] in these constitute a serious breach of the Constitution and law for which there must be consequences" (High-Level Review Panel on the SSA, 2018, p. 69). 
Dlomo, who had been dispatched by Zuma as ambassador to Japan in August 2017, was recalled by President Ramaphosa in January 2019. Since then he has mysteriously "disappeared" failing to report to the SSA for duty. In October 2019 Minister of State Security, Ayanda Dlodlo, informed parliament that Dlomo had been fired (Basson, 2019; Hunter, 2019).

During all this time, parliamentary oversight was weak, with governing-party MPs, particularly those in the security cluster, either unwilling or unable to arrest or call out executive overreach or expose the abuse of tax revenue, amounting to billions. With regard to weak oversight by parliament's Joint Standing Committee on Intelligence (JSCI), in particular, the High Level report proposed a review of the functioning of the JSCI "given the demands of intelligence oversight, the idea of a dedicated capacity for the JSCI needs to be explored further" (High-Level Review Panel on the SSA, 2018, p. 97).

\subsection{THE SECRETS OF POWER}

As argued in the Introduction chapter, for Zuma to maintain his grip on the vast and corrupt patronage network that had begun to sprawl around in office, he (and the allied power elite) needed to maintain an iron grip on the governing party itself. As preparations for the ANC's highly factionalised 54th Elective Conference, which took place at Nasrec in 2017, gathered momentum, Zuma's shadow state kicked into overdrive. By then much of the endemic corruption as well as the influence of the Gupta family had been exposed. Much of the evidence given to the Zondo Commission has since corroborated this.

In the end, Deputy President Cyril Ramaphosa scored a surprise narrow victory pipping Jacob Zuma's leadership slate, led by Nkosazana Dlamini-Zuma, by 179 votes. In spite of Jacob Zuma's access to vast resources - both financial and human including rogue SSA and specifically SAPS Crime Intelligence operatives, he failed to secure a victory for his faction. Allegations that Zuma had previously abused state resources to rig election results at the ANC's Mangaung elective conference in 2012, as well as at Nasrec, had been the focus of investigations by Independent Police Investigative Directorate's (IPID) dogged Executive Director Robert McBride, that is before parliament decided not to renew his contract (PMG, 2018a).

McBride, after receiving a tip-off in August 2017, had managed to thwart the illegal procurement by SAPS Crime Intelligence of a "grabber", a type of surveillance device, for the inflated price of R45m (it generally sells for R8m). The difference, said McBride, would have been laundered to buy votes at Nasrec in December (Thamm, 2019b). SAPS National Commissioner, Khehla Sitole, McBride repeatedly has told 
parliament, is reluctant to hand over information about the illegal attempted $\mathrm{R} 45 \mathrm{~m}$ grabber procurement claiming the documents are "classified". The IGI, Setlhomamaru Dintwe, has agreed with McBride, however, that matters of procurement cannot be "classified" especially if this was being done to cover up alleged criminality (Sole, 2019). The matter remains unresolved.

IPID under McBride was also investigating the alleged capture of SAPS and SITA (State Information Technology Agency) by private individuals who at present still have the power to "switch off" SAPS IT systems - and in so doing place the country's security at risk (PMG, 2017, 2018b, 2018a). The lack of oversight in the awarding of these dodgy tenders concluded over the years by a corrupted SAPS leadership with suppliers has been the subject of numerous Standing Committee on Public Account and court probes which are ongoing.

\subsection{CROSS HAIRS AND SLUSH FUNDS}

In 2009, Zuma appointed former apartheid-era cop Richard Mdluli to head SAPS Crime Intelligence, which has played a key a role in the SSA and the capture of the security cluster. It is a position Mdluli held until 2012, in spite of facing serious charges of fraud, corruption, kidnapping and murder. Two Zuma loyalists, acting Head of Public Prosecutions, Nomcgobo Jiba, and Lawrence Mwrebi, Head of the NPA's Commercial Crimes Unit, ensured for years that the heat was taken off Mdluli (see Chapter 13). It was Mdluli who, as Gauteng Deputy Provincial Police Commissioner, had overseen the investigation into Zuma's 2006 rape charges and it was Mdluli who headed a bogus fraud and corruption investigation into Gauteng Scorpions Head, Gerrie Nel, who was prosecuting then National Commissioner, Jackie Selebi at the time (Corruption Watch, 2012).

The Zondo Commission of Inquiry into State Capture has heard extensive evidence of how Crime Intelligence operatives were responsible for planting stories in the media, specifically the Sunday Times, in order to discredit officials who were investigating Zuma, his family and their business associates. When KZN Hawks Head, Johan Booysen, began investigating (amongst others) Durban tycoon Thoshan Panday, a friend of the Zuma family who had scored a R45m contract (with planned additional $\mathrm{R} 15 \mathrm{~m}$ ) from SAPS, Booysen soon found himself in the cross-hairs (Booysen, 2019).

A story leaked to the Sunday Times about an alleged "Cato Manor Death Squad", purportedly led by Booysen, soon saw the top cop and his team arrested on serious trumped-up charges of corruption and racketeering. All charges were later withdrawn. It was the hopelessly unqualified Berning Ntlemeza, whom Zuma appointed to head the DCPI in 2014 (Underhill, 2016). Ntlemeza replaced Anwar Dramat, who had 
initially investigated the 1999 murder and kidnapping charges against Mdluli and which were dropped by the NPA in 2012 (Booysen, 2019).

High Court Judge, Elias Motojane, in the North Gauteng High Court in February 2015, had handed down a scathing judgment with regard to Ntlemeza's illegal firing of then Gauteng Hawks Head, Shadrack Sibiya, saying he had done so in "bad faith and for reasons other than those given"(North Gauteng High Court, 2015, p. 5).

In September 2020, Panday lost his bid to escape prosecution when the Pietermaritzburg High Court confirmed a 2017 decision by then NPA head Shaun Abrahams to prosecute Panday. Panday fought the prosecution for almost a decade (Cowan, 2020b; Ellis, 2020).

Testifying at the Zondo Commission in September 2019, Hawks investigator, Kobus Roelofse, detailed Mdluli's looting of the Crime Intelligence Secret Service Account over the years. Roelofse testified that the beneficiaries of the secret service account used it as a slush fund, amongst them two Police Ministers, current incumbent Bheki Cele and his penultimate predecessor Nathi Mthethwa. But it was Mdluli himself who was the main beneficiary of the CI slush fund using taxpayers money to fund security upgrades to his homes, trips overseas with his family, as well as the purchase of five luxury vehicles totalling R3.5m (Davis, 2019; Roelofse, 2019).

The Zondo Commission also heard evidence of how, between 2009 and 2012, vehicles worth R69m were bought by Crime Intelligence from one dealer in Pretoria. Roelofse said he had been unable to prosecute a single crime intelligence official because no Police Commissioner to date had been willing to cooperate or declassify critical information (Roelofse, 2019).

This evidence to the commission is yet to be fully tested.

\subsection{UNDOING THE DAMAGE}

The value of the Mufumadi High-Level Panel review and its report is that it has made visible so much of what was deliberately hidden and obscured during the Zuma years. The panel began its top secret work in July 2018 and held interviews with "a wide range of people" including "current and former ministers of intelligence/state security; former and current directors-general and senior leadership of the SSA and its predecessor services; the Inspector-General for Intelligence, the Coordinator for Intelligence, the National Security Advisor, the Auditor General, the heads of other arms of the broader intelligence community as well as individual members and former members of the community" (High-Level Review Panel on the SSA, 2018, p.1). Current and former Heads of the National Intelligence Co-ordinating Committee 
(NICOC), Crime Intelligence, Military Intelligence, the Financial Intelligence Centre (FIC) and Directors-General of the Departments of Home and Foreign Affairs were also engaged. The panel also reviewed and had access to "an extensive number of documents, including presentations and submissions from SSA units, other sectors of the intelligence community, past and current individual members of the community and other relevant arms of government; policies, legislation, regulations and directives; previous review reports and discussion documents; investigation reports and many others" (High-Level Review Panel on the SSA, 2018, p. 1).

President Cyril Ramaphosa acted swiftly to begin the massive clean-up of the SSA and other services in light of the release of the report of the High-Level panel. During his State of the Nation Address in February 2019, Ramaphosa announced that he would re-establish and Chair the National Security Council as well as re-establish the two security arms; Domestic and Foreign Intelligence. In the State of The Nation address, February 2019, Ramaphosa said that, on the basis of the report and its recommendations, "I will soon be announcing a number of urgent steps to enable the reconstitution of a professional national intelligence capability for South Africa" (Ramaphosa, 2019).

In April 2018, Arthur Fraser was removed as DG of SSA and replaced by acting DG Loyiso Jafta, while in August 2019 Advocate Mahlodi Sam Muofhe was appointed Head of the Domestic branch. During the parliamentary debate on the State Security budget in July 2019, Minister of State Security, Ayanda Dlodlo (2019), hinted that wide-ranging reforms of the intelligence services were underway. With a budget of around R5bn, Dlodlo said the SSA faced financial pressures and was "too small" compared with international standards. Dlodlo (2019) said a skills audit of the SSA was in progress and that an independent labour expert would be brought in by the agency to deal with the backlog of disciplinary cases which remain undisclosed.

Undoing the massive damage and contagion caused by Jacob Zuma to the country's intelligence services is a mammoth undertaking but the recommendations of the High-Level panel review has provided a detailed roadmap to recovery. 


\section{References}

\#UniteBehind (2017) ‘\#PRASALEAKS Rig, Conceal, Destroy and Falsify: How State Capture Happened at PRASA', UniteBehind. [Online]. https://bit.ly/37yilhX (Accessed 3 November 2020).

Basson, A. (2019) 'The curious case of Ambassador Thulani 'Silence' Dlomo", News24. [Online]. https://bit.ly/37sQDIK (Accessed 5 November 2020).

Bhorat, H., Buthelezi, M., Chipkin, I., Duma, S., Mondi, L., Peter., C., Qobo, M., Swilling, M. \& Friedenstein, H. (2017) Betrayal of the Promise: How South Africa is being stolen, State Capacity Research Project. South Africa. [Online]. https://bit.ly/2WX3tXe

Booysen, JW. (2019) Statement and Documents Submitted by Johan Booysen, Commission of Inquiry into State Capture. Commission of Inquiry into State Capture.

Corruption Watch (2012) Richard Mdluli: a comprehensive timeline. [Online]. https://bit.ly/2VEIfwQ(Accessed 5 November 2020).

Cowan, K. (2020a) 'Intelligence watchdog's SARS 'rogue unit' report set aside, Van Loggerenberg calls on police, NPA to act', News24. [Online] https://bit.ly/3ArvW6d (Accessed 21 October 2020).

Cowan, K. (2020b) 'Thoshan Panday, coaccused to face 261 counts of corruption, fraud for SAPS tender scandal', News24. [Online]. https://bit.ly/3fDBaDB (Accessed 6 November 2020).

Davis, R. (2019) 'Bheki Cele was paid to approve restructuring of Crime Intelligence, claims Hawks investigator', Daily Maverick. [Online]. https://bit.ly/3g0bUYL (Accessed 5 November 2020).

Dlodlo, A. (2019) 'Minister Ayanda Dlodlo: State Security Agency Dept Budget Vote 2019/20 [18 Jul 2019]; South African Government. [Online]. https://bit.ly/3fCBe6P (Accessed 6 November 2020).

Ellis, E. (2020) “Untouchable’ Thoshan Panday loses battle to avoid prosecution for World Cup SAPS fraud', Daily Maverick.
[Online].https://bit.ly/3AkR1Pt (Accessed 6 November 2020).

Etheridge, J. (2019) 'Arthur Fraser issues summons against Jacques Pauw, NB Publishers for R35m', News24. [Online]. https://bit.ly/3s0tBMo (Accessed 5 November 2019).

High-Level Review Panel on the SSA (2018) High-Level Review Panel Report on the State Security Agency. [Online]. https:// bit.ly/3lGQZNL

Hunter, Q. (2019) “Zuma's spy' fights tooth and nail to get State Security job back', Times Live. [Online]. https://bit.ly/37snHtW (Accessed 5 November 2020).

Letsoala, M. \& Molele, C. (2013) ‘Ex-spy boss slams Cwele over Guptas', Mail \& Guardian. https://bit.ly/3AgybsE (Accessed 4 November 2020).

Maughan, K. (2018) 'Intelligence watchdog brands spy boss Fraser a liar', Times Live. [Online]. https://bit.ly/3AjUgqq (Accessed 3 November 2020).

Merten, M. (2017) 'Spooks and Spies: The PAN progamme, Arthur Fraser and eight years of investigations', Daily Maverick. [Online].https://bit.ly/3lHU7Jq (Accessed 3 November 2020).

Myburgh, P.-L. (2016) 'Exclusive: Zuma told "bogus union" to spy on Amcu, News24. [Online]. https://bit.ly/3fDsOfm (Accessed 5 November 2019).

Myburgh, P.-L. \& Tau, P. (2016) 'Zuma, spooks and the bogus union', City Press. [Online]. https://bit.ly/37rf V3z (Accessed 6 November 2020).

News24(2011) 'Cwele wants to keep spy service clean'. [Online].https://bit.ly/3AlYBc] (Accessed 4 November 2020).

Njenje, L. (2018) 'Statement and Documents Submitted by Lizo Njenje', Commission of Inquiry into State Capture.

North Gauteng High Court (2015) Sibiya V Minister of Police and Others (5203/2015) [2015] ZAGPPHC 135 (20 February 2015). [Online].https://bit.ly/37yiMHP (Accessed 6 November 2020). 
Office of the Inspector General of Intelligence (OIGI) (2014) Report on an Investigation into Media Allegations against Special Operations Unit and/or other Branches of the State Security Agency. Pretoria.

Pauw, J. (2017) The President's Keepers: Those keeping Zuma in Power and out of Prison. 1st Ed. Cape Town: Tafelberg.

Pheto, B. (2020) 'Court disagrees with EFF and $\mathrm{PP}$, keeps state security report secret', Times Live. [Online]. https://bit.ly/2VzGDEs (Accessed 6 November 2020).

PMG (Parliamentary Monitoring Group) (2017) SAPS irregular expenditure; Forensic Data Analysts contracts: hearing with SAPS, SITA, IPID. [Online]. https://bit.ly/2VBCjF9 (Accessed 6 November 2020).

PMG (Parliamentary Monitoring Group) (2018a) IPID investigations: progress and challenges. [Online]. https://bit.ly/ 3CtFQWL (Accessed 5 November 2020).

PMG (Parliamentary Monitoring Group) (2018b) SITA deviations and expansions: hearing. [Online]. https://bit.ly/3fHnpnr (Accessed 5 November 2020).

Public Protector (2015) Derailed. Pretoria.

Ramaphosa, C. (2019) 'State of the Nation Address by President Cyril Ramaphosa, Parliament [7 February 2019]', thepresidency. gov. [Online]. https://bit.ly/3jyY1S7 (Accessed 6 November 2020).

Republic of South Africa (1995) 'Intelligence White Paper', South African Government. [Online]. https://bitly/3fGtDUT (Accessed 5 November 2020).

Roelofse, K.D. (2019) 'Statement and Documents Submitted by Kobus Demeyer Roelofse', Commission of Inquiry into State Capture.

SAPA (2011) 'Spy boss Njenje not asked to quit lawyer', Polity.org. [Online]. https://bit.ly/ 3lHUSIK (Accessed 4 November 2020).

Shaik, R. (2019) 'Statement and Documents Submitted by Rieaz Shaik', Commission of Inquiry into State Capture.

Siqoko, B. (2018) 'We got it wrong, and for that we apologise', Sunday Times. [Online]. https://bit.ly/3fHnLdL (Accessed 5 November 2019).
Sole, S. (2019) 'SAPS Wars Part 3: Bheki Cele, Robert McBride and the mysterious $\mathrm{Mr}$ Marimuthu', amaBhungane. [Online]. https://bit.ly/3IIQVNI (Accessed 5 November 2020).

South African Government (2019) What are the government clusters and which are they?, South African Government. https://bit.ly/ 31DFBCt (Accessed 5 November 2019).

Mail \& Guardian (2009) 'The spy who saved Zuma' [Online]. https://bitly/3Aldw6P (Accessed 3 November 2020).

Thamm, M. (2019a) ‘Busisiwe Mkhwebane’s big fat fishing expedition for Radebe Report', Daily Maverick. [Online]. https://bit.ly/ 3CuOYKs (Accessed 5 November 2019).

Thamm, M. (2019b) 'NASREC PLOT: IPID targets senior SAPS members and former ministerial adviser in ANC vote-buying scandal', Daily Maverick. https://bit.ly/ 3xvKxvo (Accessed 5 November 2019).

Thamm, M. (2020) 'Judge orders that 2014 intelligence report into attack on SARS must remain secret', Daily Maverick. [Online]. https://bit.ly/3AkSQMj (Accessed 6 November 2020).

Underhill, G. (2016) 'State Capture: Nhleko’s secret Cabinet memorandum unlocks mystery of Ntlemezas appointment to lead the Hawks', Daily Maverick. [Online]. https://bit.ly/37yjnt3 (Accessed 5 November 2020).

Van Diemen, E. (2019) 'Criminal case against Zuma-linked ex-spy still 'pending", News24. [Online]. https://bit.ly/3xAmhrY (Accessed 4 May 2021).

Van Wyk, P. (2017) 'Scorpio: SA's spy boss implicated in massive tender fraud at Prasa', Daily Maverick. [Online]. https://bit.ly/ 3ivrFZi (Accessed 5 November 2019).

Zondo Commission (2019) 'Transcript from Inquiry into State Capture: Day 193 (26-11-2019) - Testimony of Rieaz Shaik \& Lizo Njenje, Commission of Inquiry into State Capture.

Zondo Commission (2020a) 'Transcript from Inquiry into State Capture: Day 215 (19-02-2020) - Testimony of Nokunqoba Dlamini and $\mathrm{Mr} Y$ ', Commission of Inquiry into State Capture. 
Zondo Commission (2020b) 'Transcript from Inquiry into State Capture: Day 216 (20-02-2020) - Testimony of Mr Y and Polani Sokombela', Commission of Inquiry into State Capture.
Zondo Commission (2020c) 'Transcript from Inquiry into State Capture: Day 231 (10-07-2020) - Testimony of Mzuvukile Maqetuka', Commission of Inquiry into State Capture. 



\section{APPENDIX}

\begin{tabular}{|c|c|c|c|c|}
\hline $\begin{array}{l}\text { Case Study } \\
\text { in State } \\
\text { Capture }\end{array}$ & Status & Summary Description & $\begin{array}{l}\text { Investigation } \\
\text { Body / } \\
\text { Source of } \\
\text { Evidence }\end{array}$ & $\begin{array}{l}\text { Government } \\
\text { Entity } \\
\text { Implicated }\end{array}$ \\
\hline \multicolumn{5}{|c|}{ Scandals Connected to Jacob Zuma, Guptas, Other Key Networks and ANC Politics } \\
\hline $\begin{array}{l}\text { The State } \\
\text { of Capture } \\
\text { report - } \\
\text { focuses } \\
\text { on Guptas' } \\
\text { relationship } \\
\text { with Jacob } \\
\text { Zuma and } \\
\text { their alleged } \\
\text { influence on } \\
\text { the affairs } \\
\text { of state }\end{array}$ & $\begin{array}{l}\text { First complaint } \\
\text { was received } \\
\text { in March } 2016 \\
\text { and the report } \\
\text { was released in } \\
\text { November } 2016 .\end{array}$ & $\begin{array}{l}\text { Investigation into complaints of alleged improper } \\
\text { and unethical conduct by the President and } \\
\text { other State Functionaries, relating to alleged } \\
\text { improper relationships and involvement of the } \\
\text { Gupta Family in the removal and appointment } \\
\text { of Ministers and Directors of State-Owned } \\
\text { Enterprises (SOEs), resulting in improper and } \\
\text { possibly corrupt award of State Contracts and } \\
\text { Benefits to the Gupta Family's Businesses. } \\
\text { The report details numerous allegations of } \\
\text { the Guptas' involvement in affairs of the state } \\
\text { and their irregular activities that enable rent } \\
\text { extraction. The findings were not conclusive } \\
\text { and the remedial action was to establish a } \\
\text { commission of inquiry into state capture (to } \\
\text { be appointed by the President, but with a } \\
\text { judge selected by the Chief Justice). Litigation } \\
\text { endeavoured to delay or prohibit the report's } \\
\text { release and implementation of remedial actions, } \\
\text { but failed, and the commission was established } \\
\text { in } 2018 \text {. }\end{array}$ & $\begin{array}{l}\text { - Public } \\
\text { Protector, } \\
\text { followed by } \\
\text { litigation }\end{array}$ & $\begin{array}{l}\text { - GCIS (The } \\
\text { New Age) } \\
\text { - Eskom } \\
\text { (Optimum) } \\
\text { - Transnet } \\
\text { (Regiments/ } \\
\text { Trillian) } \\
\text { - Denel } \\
\text { - SAA (The } \\
\text { New Age) } \\
\text { - SABC (The } \\
\text { New Age) } \\
\text { - Department of } \\
\text { Finance } \\
\text { - Transport } \\
\text { (SAA) } \\
\text { - Communica- } \\
\text { tions (SABC } \\
\text { \& GCIS) }\end{array}$ \\
\hline $\begin{array}{l}\text { Zondo } \\
\text { Commission }\end{array}$ & $\begin{array}{l}\text { Established } \\
\text { in 2018, with } \\
\text { anticipated } \\
\text { conclusion being } \\
\text { the end of } 2021 .\end{array}$ & $\begin{array}{l}\text { Formally titled the Judicial Commission of } \\
\text { Inquiry into Allegations of State Capture, } \\
\text { Corruption and Fraud in the Public Sector } \\
\text { including Organs of State, the Commission } \\
\text { was promulgated by then President Zuma in } \\
\text { response to the remedial actions as outlined in } \\
\text { the Public Protector's State of Capture report. } \\
\text { As of June } 2021 \text {, the Commission that started } \\
\text { in August } 2018 \text { has held more than } 418 \text { days } \\
\text { of hearings of over } 330 \text { testimonies (generating } \\
\text { over } 71000 \text { pages of transcript). The inquiry's } \\
\text { terms of reference were expansive and, as } \\
\text { such, the scope of investigations went beyond } \\
\text { merely looking into the Gupta-related cases, } \\
\text { covering other networks (e.g., Bosasa) as well } \\
\text { as other government institutions (e.g., role } \\
\text { of Parliament). }\end{array}$ & $\begin{array}{l}\text { - Zondo } \\
\text { Commission }\end{array}$ & $\begin{array}{l}\text { Various } \\
\text { work-streams } \\
\text { covering } \\
\text { inter alia: } \\
\text { - SOEs } \\
\text { (Eskom, } \\
\text { Transnet, } \\
\text { Denel, SAA) } \\
\text { - Free State } \\
\quad \text { Provincial } \\
\text { Government } \\
\text { - Bosasa } \\
\text { - SARS } \\
\text { - Law } \\
\text { enforcement } \\
\text { - State Security } \\
\text { Agency (SSA) } \\
\text { - The New Age } \\
\text { \& ANN7 } \\
\text { - Role of } \\
\text { Parliament } \\
\text { and ANC }\end{array}$ \\
\hline
\end{tabular}




\begin{tabular}{|c|c|c|c|c|}
\hline $\begin{array}{l}\text { Case Study } \\
\text { in State } \\
\text { Capture }\end{array}$ & Status & Summary Description & $\begin{array}{l}\text { Investigation } \\
\text { Body / } \\
\text { Source of } \\
\text { Evidence }\end{array}$ & $\begin{array}{l}\text { Government } \\
\text { Entity } \\
\text { Implicated }\end{array}$ \\
\hline \multicolumn{5}{|c|}{ Scandals Connected to Jacob Zuma, Guptas, Other Key Networks and ANC Politics } \\
\hline Bosasa & $\begin{array}{l}\text { Dating back to a } \\
2009 \text { SIU report. } \\
\text { Investigations and } \\
\text { various litigations } \\
\text { are ongoing. }\end{array}$ & $\begin{array}{l}\text { In 2019, former Bosasa C00, Anglo Agrizzi, } \\
\text { testified at the Zondo Commission, detailing } \\
\text { the acts and long history of corruption between } \\
\text { various Bosasa companies predominantly } \\
\text { owned by Gavin Watson, and numerous } \\
\text { government entities/departments. The } \\
\text { testimony of Agrizzi (and other former Bosasa } \\
\text { employees) corroborated the findings of a } \\
2009 \text { SIU investigation that alleged corruption } \\
\text { in several contracts Bosasa had with the } \\
\text { Department of Correctional Services. Criminal } \\
\text { court proceedings have been initiated based } \\
\text { on the } 2009 \text { SIU investigation, along with new } \\
\text { investigations initiated by SARS and other law } \\
\text { enforcement entities. }\end{array}$ & $\begin{array}{l}\text { - Special } \\
\text { Investi- } \\
\text { gation } \\
\text { Unit (SIU) } \\
\text { - Zondo } \\
\text { Commission }\end{array}$ & $\begin{array}{l}\text { - Department of } \\
\text { Correctional } \\
\text { Services } \\
\text { - Department of } \\
\text { Justice } \\
\text { - Department of } \\
\text { Home Affairs } \\
\text { - Department of } \\
\text { Transport } \\
\text { - Various SOEs } \\
\text { (e.g., SAPO, } \\
\text { ACSA) } \\
\text { - National } \\
\text { Prosecuting } \\
\text { Authority } \\
\text { (NPA) } \\
\text { - Members of } \\
\text { Parliament }\end{array}$ \\
\hline Arms Deal & $\begin{array}{l}\text { Various } \\
\text { investigations and } \\
\text { sources, dating } \\
\text { back to 1990s. } \\
\text { Most significant } \\
\text { source being } \\
\text { through Seriti } \\
\text { Commission. } \\
\text { Corruption case } \\
\text { against Zuma is } \\
\text { ongoing. }\end{array}$ & $\begin{array}{l}\text { Commission of Inquiry into allegations of fraud, } \\
\text { corruption, impropriety, or irregularity in the } \\
\text { Strategic Defence Procurement Packages } \\
\text { (SDPP). Various court cases related to } \\
\text { allegations of corruption against Jacob Zuma. } \\
\text { On Monday, } 24 \text { October 2011, the President } \\
\text { announced the Commission chaired by Judge } \\
\text { Seriti. The findings of the Commission were that } \\
\text { there was "no evidence" of corruption, but this } \\
\text { is seen by many to have been a whitewash. The } \\
\text { report was taken on review and set aside in } \\
\text { August } 2019 \text {. The corruption case against Zuma } \\
\text { is ongoing before the courts. }\end{array}$ & $\begin{array}{l}\text { - Seriti } \\
\text { Commission } \\
\text { - Various } \\
\text { court cases }\end{array}$ & $\begin{array}{l}\text { Initially: } \\
\text { - South African } \\
\text { National } \\
\text { Defence } \\
\text { Force } \\
\text { - Members of } \\
\text { Parliament } \\
\text { Allegations also } \\
\text { involve: } \\
\text { - NPA } \\
\text { - SSA }\end{array}$ \\
\hline $\begin{array}{l}\text { Nkandla } \\
\text { Security } \\
\text { Upgrades }\end{array}$ & $\begin{array}{l}\text { Investigation } \\
\text { started in } \\
\text { November } 2012 . \\
\text { Report on } \\
\text { investigation } \\
\text { was released in } \\
\text { March } 2014 .\end{array}$ & $\begin{array}{l}\text { Report on security upgrades to President } \\
\text { Zuma's homestead in Nkandla. The investigation } \\
\text { found that the President unduly benefited from } \\
\text { the upgrades and as part of remedial actions } \\
\text { the President was required to pay back a portion } \\
\text { of the costs of the upgrades. Zuma instructed } \\
\text { that SAPS undertake their own investigation, } \\
\text { which sought to rationalise the expenses (fire- } \\
\text { pool report). Parliament accepted this alternative } \\
\text { report, but major court cases followed, } \\
\text { ultimately declaring that the Public Protector's } \\
\text { remedial actions are binding. President and } \\
\text { Parliament failed to uphold the Constitution. } \\
\text { President ordered to "pay back the money". }\end{array}$ & $\begin{array}{l}\text { - Public } \\
\text { Protector's } \\
\text { Secured } \\
\text { in Comfort } \\
\text { report, } \\
\text { followed by } \\
\text { litigation }\end{array}$ & 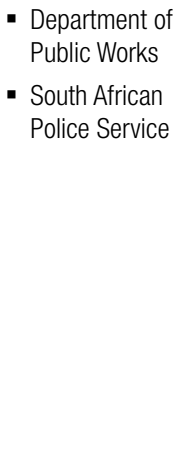 \\
\hline
\end{tabular}




\begin{tabular}{|c|c|c|c|c|}
\hline $\begin{array}{l}\text { Case Study } \\
\text { in State } \\
\text { Capture }\end{array}$ & Status & Summary Description & $\begin{array}{l}\text { Investigation } \\
\text { Body / } \\
\text { Source of } \\
\text { Evidence }\end{array}$ & $\begin{array}{l}\text { Government } \\
\text { Entity } \\
\text { Implicated }\end{array}$ \\
\hline \multicolumn{5}{|c|}{ Scandals Connected to Jacob Zuma, Guptas, Other Key Networks and ANC Politics } \\
\hline $\begin{array}{l}\text { Private } \\
\text { Aircraft } \\
\text { Landing at } \\
\text { Waterkloof } \\
\text { Airforce Base } \\
\text { and Gupta } \\
\text { Sun City } \\
\text { Wedding }\end{array}$ & May 2013. & $\begin{array}{l}\text { In 2013, justice, crime prevention, and } \\
\text { security cluster (JCPS) - a cabinet structure } \\
\text { composed of various ministries - undertook an } \\
\text { investigation into the Landing of a Commercial } \\
\text { aircraft at Air Force Base Waterkloof (report } \\
\text { titled the same). The investigation revealed that } \\
\text { the Guptas initially tried to organise a special } \\
\text { landing at OR Tambo International Airport, but } \\
\text { was turned down. They then approached the } \\
\text { Indian High Commission who re-designated the } \\
\text { wedding entourage as an official delegation to } \\
\text { secure a landing at the Waterkloof base. The } \\
\text { wedding held at Sun City was attended by a } \\
\text { number of high-profile ANC politicians and was } \\
\text { paid for in part by moneys looted from the Vrede } \\
\text { Dairy Farm project. }\end{array}$ & $\begin{array}{l}\text { - Report by } \\
\text { JPCS } \\
\text { - Zondo } \\
\text { Commission }\end{array}$ & $\begin{array}{l}\text { - Department of } \\
\text { International } \\
\text { Relations and } \\
\text { Cooperation } \\
\text { (DIRCO) } \\
\text { - Department of } \\
\text { Defence } \\
\text { - Department of } \\
\text { Transport }\end{array}$ \\
\hline $\begin{array}{l}\text { Free State } \\
\text { Provincial } \\
\text { Capture, } \\
\text { includes } \\
\text { Vrede Dairy } \\
\text { Farm and } \\
\text { Asbestos } \\
\text { Contracts }\end{array}$ & Ongoing. & $\begin{array}{l}\text { The Vrede Dairy Farm project was initiated } \\
\text { by the Free State Provincial Government as a } \\
\text { development project, however, in partnering with } \\
\text { a Gupta-linked company Estina, government } \\
\text { funds were looted. In 2018, the Public } \\
\text { Protector released a report on their } 2018 \\
\text { investigation, but it was taken on review and } \\
\text { set aside by the courts. The second part of the } \\
\text { investigation is yet to be finalised. The NPA } \\
\text { laid criminal charges against Gupta associates } \\
\text { and implicated government officials. Court } \\
\text { proceedings are ongoing. } \\
\text { Significant testimony and evidence have been } \\
\text { presented at the Zondo Commission regarding } \\
\text { the Vrede Farm case, as well as the asbestos } \\
\text { inspection project (criminal proceedings are also } \\
\text { underway). Both projects implicate high-profile } \\
\text { politicians and senior officials manipulating } \\
\text { government process. }\end{array}$ & $\begin{array}{l}\text { - } \text { Public } \\
\text { Protector } \\
\text { reports } \\
\text { - Zondo } \\
\text { Commission } \\
\text { - Various } \\
\text { court cases }\end{array}$ & $\begin{array}{l}\text { - Free State } \\
\text { Provincial } \\
\text { Government }\end{array}$ \\
\hline $\begin{array}{l}\text { Irregular } \\
\text { removal of } \\
\text { National } \\
\text { Director } \\
\text { of Public } \\
\text { Prosecutions } \\
\text { (NDPP), } \\
\text { Mxolisi } \\
\text { Nxasana }\end{array}$ & $\begin{array}{l}\text { Inquiry instituted } \\
\text { in February } 2015, \\
\text { but was cancelled } \\
\text { in May } 2015 . \\
\text { This triggers the } \\
\text { Constitutional Court } \\
\text { cases that followed. }\end{array}$ & $\begin{array}{l}\text { Inquiry into the fitness of Mxolisi Nxasana to } \\
\text { hold office as NDPP. The Inquiry was cancelled } \\
\text { after Zuma "agreed to let Nxasana resign". He } \\
\text { was paid R17m - the balance of his ten-year } \\
\text { contract. Court cases followed detailing the } \\
\text { abuse of the presidency powers by Zuma. } \\
\text { Ultimately, Nxasana was ordered to repay } \\
\text { R17m and Zuma's appointed replacement, } \\
\text { Shawn Abrahams, was ordered to vacate office. } \\
\text { Constitutional Court found Zuma's actions to } \\
\text { be an abuse of power and in breach of his } \\
\text { constitutional obligations. }\end{array}$ & $\begin{array}{l}\text { - Cassim } \\
\text { Inquiry into } \\
\text { fitness of } \\
\text { Mxolisi } \\
\text { Nxasana to } \\
\text { hold office } \\
\text { of NDPP } \\
\text { initiated } \\
\text { by Zuma, } \\
\text { followed by } \\
\text { litigation }\end{array}$ & $\begin{array}{l}\text { - National } \\
\text { Prosecution } \\
\text { Authority }\end{array}$ \\
\hline $\begin{array}{l}\text { Political } \\
\text { killings in } \\
\text { KZN }\end{array}$ & $\begin{array}{l}\text { Established in } \\
\text { October } 2016 . \text { The } \\
\text { report was released } \\
\text { in May } 2018 .\end{array}$ & $\begin{array}{l}\text { On } 28 \text { October 2016, the Premier of the } \\
\text { Province of KwaZulu-Natal established a } \\
\text { Commission of Enquiry into the Underlying } \\
\text { Causes of the Murder of Politicians in KwaZulu- } \\
\text { Natal (KZN). }\end{array}$ & $\begin{array}{l}\text { - Moerane } \\
\text { Commission } \\
\text { of Enquiry }\end{array}$ & $\begin{array}{l}\text { - KZN Provincial } \\
\text { Government } \\
\text { - KZN Local } \\
\text { Governments }\end{array}$ \\
\hline
\end{tabular}




\begin{tabular}{|c|c|c|c|c|}
\hline $\begin{array}{l}\text { Case Study } \\
\text { in State } \\
\text { Capture }\end{array}$ & Status & Summary Description & $\begin{array}{l}\text { Investigation } \\
\text { Body / } \\
\text { Source of } \\
\text { Evidence } \\
\end{array}$ & $\begin{array}{l}\text { Government } \\
\text { Entity } \\
\text { Implicated }\end{array}$ \\
\hline \multicolumn{5}{|c|}{ Scandals Connected to Jacob Zuma, Guptas, Other Key Networks and ANC Politics } \\
\hline \multicolumn{5}{|c|}{ State Capture of State-Owned Enterprises and Government Departments } \\
\hline $\begin{array}{l}\text { Interference } \\
\text { in operations } \\
\text { at the SABC }\end{array}$ & $\begin{array}{l}\text { The Ad Hoc } \\
\text { Committee was } \\
\text { established in } \\
\text { November } 2016 \\
\text { and final report } \\
\text { was tabled on } \\
24 \text { February } 2017 .\end{array}$ & $\begin{array}{l}\text { Parliamentary Ad Hoc Committee on the } \\
\text { SABC Board Inquiry into mismanagement and } \\
\text { interference in SABC operations. Findings } \\
\text { include evidence of Minister Faith Muthambi's } \\
\text { interference in the organisation and editorial } \\
\text { interference, in the firing of SABC } 8 \text { who } \\
\text { protested censorship of the national broadcaster } \\
\text { (on instruction from COO Hlaudi Motsoeneng). It } \\
\text { should be noted that the inquiry was preceded } \\
\text { by an investigation by the Public Protector. } \\
\text { Details are contained in the } 2014 \text { report titled } \\
\text { When Governance and Ethics Fail. }\end{array}$ & $\begin{array}{l}\text { - Parliamen- } \\
\text { tary Inquiry } \\
\text { - Preceded by } \\
\text { an investi- } \\
\text { gation by } \\
\text { the Public } \\
\text { Protector }\end{array}$ & $\begin{array}{l}\text { - SABC } \\
\text { (Department } \\
\text { of Communi- } \\
\text { cation) }\end{array}$ \\
\hline \multirow[t]{2}{*}{$\begin{array}{l}\text { Passenger } \\
\text { Rail Agency } \\
\text { of South } \\
\text { Africa } \\
\text { (PRASA) }\end{array}$} & $\begin{array}{l}\text { Complaints were } \\
\text { lodged in } 2012 \\
\text { and the report } \\
\text { was released in } \\
\text { August } 2015 .\end{array}$ & $\begin{array}{l}\text { Several cases of "mismanagement and } \\
\text { irregularities" regarding various contracts. } \\
\text { Lucky Montana was CEO at the time. One of } \\
\text { the remedial actions stipulated that National } \\
\text { Treasury was to investigate all PRASA contracts } \\
\text { from } 2012 \text { onwards with a value of R10 million } \\
\text { or more. National Treasury implemented the } \\
\text { remedial action which resulted in several } \\
\text { investigations, the details of which were leaked } \\
\text { to the public. }\end{array}$ & $\begin{array}{l}\text { - Public } \\
\text { Protector's } \\
\text { Derailed } \\
\text { report on } \\
\text { PRASA } \\
\text { - Numerous } \\
\text { investiga- } \\
\text { tions }\end{array}$ & $\begin{array}{l}\text { - PRASA } \\
\text { - Department of } \\
\text { Transport }\end{array}$ \\
\hline & $\begin{array}{l}\text { In June } 2017, \\
\text { Parliament directed } \\
4 \text { committees to } \\
\text { investigate state } \\
\text { capture. Committee } \\
\text { hearings were not } \\
\text { completed. }\end{array}$ & $\begin{array}{l}\text { In terms of the parliamentary directive, the } \\
\text { Portfolio Committee on Transport was requested } \\
\text { to establish an Inquiry into State Capture at } \\
\text { PRASA. However, the Portfolio Committee noted } \\
\text { that PRASA was not mentioned in the Public } \\
\text { Protector's State of Capture report and decided } \\
\text { they would focus on the various investigation } \\
\text { reports produced for National Treasury (as } \\
\text { recommended in Derailed report). }\end{array}$ & $\begin{array}{l}\text { - Portfolio } \\
\text { Committee } \\
\text { on Transport }\end{array}$ & $\begin{array}{l}\text { - PRASA } \\
\text { - Department of } \\
\text { Transport }\end{array}$ \\
\hline $\begin{array}{l}\text { Eskom } \\
\text { Inquiry into } \\
\text { State Capture }\end{array}$ & $\begin{array}{l}\text { In June } 2017 \text {, } \\
\text { Parliament directed } \\
4 \text { committees } \\
\text { to investigate } \\
\text { state capture. } \\
\text { Public Enterprises } \\
\text { Committee } \\
\text { report on Eskom } \\
\text { was released in } \\
\text { November } 2018 .\end{array}$ & $\begin{array}{l}\text { Extensive hearings were held by the Committee } \\
\text { detailing much of the evidence presented in } \\
\text { the Public Protector's report. The Committee } \\
\text { presented recommendations and compiled } \\
\text { a final report detailing their findings. These } \\
\text { included findings that Ministers Lynne Brown } \\
\text { and Malusi Gigaba were negligent and had to } \\
\text { be held accountable. Also recommended that } \\
\text { criminal investigations be undertaken against } \\
\text { the relevant Eskom executives. }\end{array}$ & $\begin{array}{l}\text { - Parliamen- } \\
\text { tary Inquiry }\end{array}$ & $\begin{array}{l}\text { - Eskom } \\
\text { - Department } \\
\text { of Public } \\
\text { Enterprises }\end{array}$ \\
\hline $\begin{array}{l}\text { Nugent } \\
\text { Commission } \\
\text { - SARS } \\
\text { Inquiry }\end{array}$ & $\begin{array}{l}\text { The Inquiry was } \\
\text { constituted on } \\
24 \text { May } 2018 \text { and } \\
\text { the final report } \\
\text { was released in } \\
\text { December } 2018 .\end{array}$ & $\begin{array}{l}\text { Commission of Inquiry into tax administration } \\
\text { and governance by South African Revenue } \\
\text { Service (SARS). Tom Moyane was fired based on } \\
\text { the interim report released in September } 2018 . \\
\text { The inquiry found that Moyane, with the help of } \\
\text { consultancy company Bain, had implemented } \\
\text { restructuring of the organisation, resulting in } \\
\text { gross mismanagement and erosion of SARS. } \\
\text { Moyane motivated the restructuring based on } \\
\text { the "rogue unit" narrative that has been the } \\
\text { subject of several other debunked investigations } \\
\text { and the subject of much litigation. }\end{array}$ & $\begin{array}{l}\text { - Judicial } \\
\text { Commission } \\
\text { of Inquiry } \\
\text { - Court cases } \\
\text { around the } \\
\text { "rogue unit" } \\
\text { narrative }\end{array}$ & $\begin{array}{l}\text { - SARS } \\
\text { (National } \\
\text { Treasury) }\end{array}$ \\
\hline
\end{tabular}




\begin{tabular}{|c|c|c|c|c|}
\hline $\begin{array}{l}\text { Case Study } \\
\text { in State } \\
\text { Capture }\end{array}$ & Status & Summary Description & $\begin{array}{l}\text { Investigation } \\
\text { Body / } \\
\text { Source of } \\
\text { Evidence }\end{array}$ & $\begin{array}{l}\text { Government } \\
\text { Entity } \\
\text { Implicated }\end{array}$ \\
\hline \multicolumn{5}{|c|}{ Scandals Connected to Jacob Zuma, Guptas, Other Key Networks and ANC Politics } \\
\hline \multicolumn{5}{|c|}{ State Capture of State-Owned Enterprises and Government Departments } \\
\hline $\begin{array}{l}\text { Commission } \\
\text { of Inquiry } \\
\text { into Public } \\
\text { Investment } \\
\text { Corporation } \\
\text { (PIC) }\end{array}$ & $\begin{array}{l}\text { In October } 2018 \text {, } \\
\text { the Commission } \\
\text { was constituted, } \\
\text { and the final report } \\
\text { was released in } \\
\text { March } 2020 .\end{array}$ & $\begin{array}{l}\text { Commission of Inquiry into allegations of } \\
\text { impropriety regarding Public Investment } \\
\text { Corporation (PIC). There were extensive hearings } \\
\text { on various 'dodgy' deals the PIC entered } \\
\text { into and details of political and executive } \\
\text { interference in the operations and decision- } \\
\text { making processes of the investment agency. }\end{array}$ & $\begin{array}{l}\text { - Judicial } \\
\text { Commission } \\
\text { of Inquiry }\end{array}$ & $\begin{array}{l}\text { - PIC (National } \\
\text { Treasury) }\end{array}$ \\
\hline $\begin{array}{l}\text { South African } \\
\text { Social } \\
\text { Security } \\
\text { Agency } \\
\text { (SASSA) }\end{array}$ & $\begin{array}{l}\text { Various } \\
\text { Constitutional Court } \\
\text { cases from } 2011 \\
\text { to } 2018 \text { resulted } \\
\text { in removal of CPS } \\
\text { as service provider } \\
\text { to SASSA. }\end{array}$ & $\begin{array}{l}\text { In 2014, South African Social Security Agency's } \\
\text { (SASSA) } 2012 \text { contract with CPS was found } \\
\text { to be irregular and invalid, however, due to the } \\
\text { importance of ensuring beneficiaries received } \\
\text { grants, CPS continued to be the service } \\
\text { providers until } 2018 \text {. Following a March } 2017 \\
\text { ruling, the Constitutional Court instituted a } \\
\text { Section } 38 \text { Inquiry into Minister Bathabile } \\
\text { Dlamini's personal liability for the narrowly } \\
\text { averted grant payment crisis. }\end{array}$ & $\begin{array}{l}\text { Primary } \\
\text { sources: } \\
\text { - AllPay court } \\
\text { case } \\
\text { - Black Sash } \\
\text { court case }\end{array}$ & - SASSA \\
\hline $\begin{array}{l}\text { South African } \\
\text { Airways (SAA) } \\
\text { and SAA } \\
\text { Technical }\end{array}$ & $\begin{array}{l}\text { Court case } \\
\text { to have Dudu } \\
\text { Myeni declared a } \\
\text { delinquent director } \\
\text { was launched } \\
\text { in } 2017 .\end{array}$ & $\begin{array}{l}\text { Court case was launched in } 2017 \text { by Outa and } \\
\text { the SAA Pilots' Association (SAAPA) to declare } \\
\text { Myeni a delinquent director in terms of the } \\
\text { Companies Act, based on her actions while she } \\
\text { was chairperson of the SAA Board. In 2020, the } \\
\text { High Court declared Myeni a delinquent director } \\
\text { for life. A significant amount of new evidence } \\
\text { also emerged through the Zondo Commission, } \\
\text { outlining how the operations at SAA were } \\
\text { undermined and how Myeni and others abused } \\
\text { their positions of authority. }\end{array}$ & $\begin{array}{l}\text { - Court } \\
\text { papers } \\
\text { - Zondo } \\
\text { Commission }\end{array}$ & $\begin{array}{l}\text { - SAA } \\
\text { - SAA Technical }\end{array}$ \\
\hline $\begin{array}{l}\text { Gupta Family } \\
\text { Naturalisation }\end{array}$ & $\begin{array}{l}\text { In June } 2017, \\
\text { Parliament directed } \\
4 \text { committees to } \\
\text { investigate state } \\
\text { capture. Final } \\
\text { report was tabled } \\
14 \text { March } 2019 .\end{array}$ & $\begin{array}{l}\text { Portfolio Committee on Home Affairs Inquiry into } \\
\text { the Gupta Family Naturalisation was established } \\
\text { in terms of the Parliamentary directive. Hearings } \\
\text { formally started on } 12 \text { September 2018. Final } \\
\text { report was tabled on } 14 \text { March 2019. Questions } \\
\text { were raised around contracts with Visa } \\
\text { Facilitation Services. This matter is ongoing as } \\
\text { of December } 2020 \text {. }\end{array}$ & $\begin{array}{l}\text { - Portfolio } \\
\text { Committee } \\
\text { on Home } \\
\text { Affairs }\end{array}$ & $\begin{array}{l}\text { - Department of } \\
\text { Home Affairs }\end{array}$ \\
\hline $\begin{array}{l}\text { Inquiry into } \\
\text { State Capture } \\
\text { related to } \\
\text { Gupta-owned } \\
\text { mines }\end{array}$ & $\begin{array}{l}\text { In June } 2017, \\
\text { Parliament directed } \\
4 \text { committees } \\
\text { to investigate } \\
\text { state capture. }\end{array}$ & $\begin{array}{l}\text { Though the Committee drafted a term of } \\
\text { reference for the Inquiry, the activities of holding } \\
\text { hearings and consolidating the evidence never } \\
\text { materialised beyond questions being put to then } \\
\text { Minister Zwane. }\end{array}$ & $\begin{array}{l}\text { - Portfolio } \\
\text { Committee } \\
\text { on Mineral } \\
\text { Resources }\end{array}$ & $\begin{array}{l}\text { - Department } \\
\text { of Mineral } \\
\text { Resources }\end{array}$ \\
\hline
\end{tabular}




\begin{tabular}{|c|c|c|c|c|}
\hline $\begin{array}{l}\text { Case Study } \\
\text { in State } \\
\text { Capture }\end{array}$ & Status & Summary Description & $\begin{array}{l}\text { Investigation } \\
\text { Body / } \\
\text { Source of } \\
\text { Evidence }\end{array}$ & $\begin{array}{l}\text { Government } \\
\text { Entity } \\
\text { Implicated }\end{array}$ \\
\hline \multicolumn{5}{|c|}{ Scandals Connected to Jacob Zuma, Guptas, Other Key Networks and ANC Politics } \\
\hline \multicolumn{5}{|c|}{ State Capture of State-Owned Enterprises and Government Departments } \\
\hline \multirow{3}{*}{$\begin{array}{l}\text { Various } \\
\text { investigations } \\
\text { relating to } \\
\text { State Capture } \\
\text { at Eskom }\end{array}$} & 2015 & $\begin{array}{l}\text { In } 2015 \text {, Dentons produced an interim report } \\
\text { on their investigations into Status of Business } \\
\text { and Challenges at Eskom. Their investigation } \\
\text { was halted. }\end{array}$ & - Eskom & - Eskom \\
\hline & \multirow[t]{2}{*}{2017} & $\begin{array}{l}\text { In 2017, PricewaterhouseCoopers (PwC) was } \\
\text { appointed by National Treasury to investigate } \\
\text { Eskom's Coal Procurement Processes. Damning } \\
\text { findings were made in relation to Gupta-owned } \\
\text { Tegeta mine contracts and poor coal quality. }\end{array}$ & - Eskom & - Eskom \\
\hline & & $\begin{array}{l}\text { G9 was contracted by Eskom to investigate } \\
\text { the Trillian/McKinsey contracts. Interim report } \\
\text { presented to Board of Eskom in August } 2017 . \\
\text { The investigation remained incomplete, and } \\
\text { no report is available in the public domain. } \\
\text { Evidence from the investigation was presented } \\
\text { in the Parliamentary Inquiry into Eskom } \\
\text { State Capture. }\end{array}$ & $\begin{array}{l}\text { - National } \\
\text { Treasury }\end{array}$ & - Eskom \\
\hline $\begin{array}{l}\text { National } \\
\text { Treasury } \\
\text { Fundudzi } \\
\text { reports, } \\
\text { related to } \\
\text { Eskom and } \\
\text { Transnet (x3) }\end{array}$ & $\begin{array}{l}\text { Final reports } \\
\text { compiled in } \\
\text { November } 2018 \\
\text { and released to } \\
\text { the public shortly } \\
\text { thereafter. }\end{array}$ & $\begin{array}{l}\text { Investigations requested by National Treasury } \\
\text { of alleged corruption at Transnet and Eskom. } \\
\text { The three reports focused on Eskom (general), } \\
\text { the contracts related to Trillian/McKinsey and } \\
\text { Transnet Locomotives. }\end{array}$ & $\begin{array}{l}\text { - National } \\
\text { Treasury } \\
\text { Fundudzi }\end{array}$ & $\begin{array}{l}\text { - Eskom } \\
\text { - Transnet }\end{array}$ \\
\hline \multirow[t]{2}{*}{$\begin{array}{l}\text { Transnet } \\
\text { Locomotive } \\
\text { Contracts }\end{array}$} & \multirow[t]{2}{*}{$\begin{array}{l}\text { Investigations } \\
\text { commenced in } \\
\text { December } 2017 \\
\text { and reports on } \\
\text { findings submitted } \\
\text { during } 2018 .\end{array}$} & $\begin{array}{l}\text { Werksmans Attorneys was appointed in } \\
\text { December } 2017 \text { to undertake an investigation } \\
\text { into the } 1064 \text { Transnet Locomotives } \\
\text { procurement process, however, the investigation } \\
\text { was halted. No report in the public domain. }\end{array}$ & - Werksmans & - Transnet \\
\hline & & $\begin{array}{l}\text { Mncedisi Ndlovu \& Sedumedi (MNS) Attorneys } \\
\text { was then appointed to investigate } 1064 \\
\text { locomotives procurement process. The report } \\
\text { is not in the public domain, but media indicates } \\
\text { that recommendations mirror the Werksmans' } \\
\text { findings and recommends that Molefe face } \\
\text { criminal charges. }\end{array}$ & $\begin{array}{l}\text { - Mncedisi } \\
\text { Ndlovu \& } \\
\text { Sedumedi }\end{array}$ & - Transnet \\
\hline $\begin{array}{l}\text { Inquiry into } \\
\text { State Capture } \\
\text { at Transnet } \\
\text { and Denel }\end{array}$ & \begin{tabular}{l|} 
In June 2017, \\
Parliament directed \\
4 committees to \\
investigate state \\
capture. Committee \\
hearings were not \\
completed.
\end{tabular} & $\begin{array}{l}\text { A detailed information booklet was prepared } \\
\text { in relation to Transnet, however, hearings were } \\
\text { not held before the end of term of Parliament. } \\
\text { Following National elections in 2019, it } \\
\text { was decided that outstanding Inquiries into } \\
\text { state capture be postponed indefinitely until } \\
\text { conclusion of the Zondo Commission. }\end{array}$ & $\begin{array}{l}\text { - Portfolio } \\
\text { Committee } \\
\text { on Public } \\
\text { Enterprises }\end{array}$ & $\begin{array}{l}\text { - Transnet } \\
\text { - Denel }\end{array}$ \\
\hline
\end{tabular}




\begin{tabular}{|c|c|c|c|c|}
\hline $\begin{array}{l}\text { Case Study } \\
\text { in State } \\
\text { Capture }\end{array}$ & Status & Summary Description & $\begin{array}{l}\text { Investigation } \\
\text { Body / } \\
\text { Source of } \\
\text { Evidence }\end{array}$ & $\begin{array}{l}\text { Government } \\
\text { Entity } \\
\text { Implicated }\end{array}$ \\
\hline \multicolumn{5}{|c|}{ Scandals Connected to Jacob Zuma, Guptas, Other Key Networks and ANC Politics } \\
\hline \multicolumn{5}{|c|}{ Law Enforcement and the Security Cluster } \\
\hline $\begin{array}{l}\text { Enquiry into } \\
\text { Jiba and } \\
\text { Mrwebi's } \\
\text { fitness to } \\
\text { hold office } \\
\text { at NPA }\end{array}$ & $\begin{array}{l}\text { Established in } \\
\text { November } 2018 . \\
\text { Report was issued } \\
\text { in April } 2019 .\end{array}$ & $\begin{array}{l}\text { Presidential Enquiry into the fitness to hold } \\
\text { office of suspended NPA senior advocates } \\
\text { Nomgcobo Jiba and Lawrence Mrwebi. NPA's } \\
\text { deputy head Jiba, and Mrwebi, the head of } \\
\text { the Specialised Commercial Crimes Unit, were } \\
\text { suspended in October } 2018 \text { by President Cyril } \\
\text { Ramaphosa. The Inquiry was headed by retired } \\
\text { Constitutional Court Justice Yvonne Mokgoro. } \\
\text { Jiba and Mrwebi were accused of improper } \\
\text { conduct in their handling of cases involving } \\
\text { former crime intelligence head Richard Mdluli, } \\
\text { as well as former KwaZulu-Natal Hawks boss } \\
\text { Johan Booysen. }\end{array}$ & $\begin{array}{c}\text { - Mokgoro } \\
\text { Enquiry }\end{array}$ & $\begin{array}{l}\text { - } \text { National } \\
\text { Prosecuting } \\
\text { Authority }\end{array}$ \\
\hline $\begin{array}{l}\text { High-Level } \\
\text { Review Panel } \\
\text { on the State } \\
\text { Security } \\
\text { Agency (SSA) }\end{array}$ & $\begin{array}{l}\text { Established in June } \\
2018 \text { and final } \\
\text { report was sent to } \\
\text { the President in } \\
\text { December } 2018 .\end{array}$ & $\begin{array}{l}\text { The High-Level Review Panel into the SSA } \\
\text { was established by President Ramaphosa in } \\
\text { June 2018. The key finding was a serious } \\
\text { politicisation and factionalisation of the } \\
\text { intelligence community over the past decade } \\
\text { or more. This resulted in "an almost complete } \\
\text { disregard for the Constitution, policy, legislation } \\
\text { and other prescripts, and [turned] our civilian } \\
\text { intelligence community into a private resource } \\
\text { to serve the political and personal interests of } \\
\text { particular individuals" (High-Level Review Panel } \\
\text { on the SSA, 2018, p.ii). }\end{array}$ & $\begin{array}{l}\text { - Review } \\
\text { Panel } \\
\text { established } \\
\text { by President } \\
\text { Ramaphosa }\end{array}$ & - SSA \\
\hline $\begin{array}{l}\text { Various court } \\
\text { cases against } \\
\text { persons } \\
\text { within law } \\
\text { enforcement }\end{array}$ & Ongoing. & $\begin{array}{l}\text { Though testimony and evidence have been } \\
\text { presented at the Zondo Commission, it is } \\
\text { understood that no definitive findings will be } \\
\text { made regarding the capture of law enforcement } \\
\text { under the Zuma administration. Since } 2012 \\
\text { onwards, there were several court cases } \\
\text { that were pursued against individuals in law } \\
\text { enforcement, all of which have been either } \\
\text { dismissed or withdrawn. Most noteworthy are } \\
\text { the cases involved, amongst others: Anwa } \\
\text { Dramat and Shadrack Sibiya of the Hawks } \\
\text { (and Robert McBride from Independent Police } \\
\text { Investigative Directorate [IPID]) for allegations } \\
\text { related to the "Zimbabwean rendition" matter; } \\
\text { Johan Booysen for alleged racketeering as part } \\
\text { of "Cato Manor hit squad"; and the various } \\
\text { senior officials accused of being part of the } \\
\text { "rogue" intelligence unit at SARS. Other court } \\
\text { cases that have provided significant evidence } \\
\text { indicating the capture of law enforcement relate } \\
\text { to the irregular appointed allies of the Shadow } \\
\text { State capture network or the irrational removal } \\
\text { of potential opponents holding senior positions } \\
\text { in law enforcement. Example is the irregular } \\
\text { removal of Mxolisi Nxasana as National Director } \\
\text { of Public Prosecutions (NDPP). }\end{array}$ & $\begin{array}{l}\text { - Various } \\
\text { court cases, } \\
\text { proceedings } \\
\text { in Parlia- } \\
\text { ment } \\
\text { - Zondo } \\
\text { Commission }\end{array}$ & $\begin{array}{l}\text { - NPA } \\
\text { - SAPS } \\
\text { - Hawks } \\
\text { - IPID }\end{array}$ \\
\hline
\end{tabular}




\begin{tabular}{|c|c|c|c|c|}
\hline $\begin{array}{l}\text { Case Study } \\
\text { in State } \\
\text { Capture }\end{array}$ & Status & Summary Description & $\begin{array}{l}\text { Investigation } \\
\text { Body / } \\
\text { Source of } \\
\text { Evidence }\end{array}$ & $\begin{array}{l}\text { Government } \\
\text { Entity } \\
\text { Implicated }\end{array}$ \\
\hline \multicolumn{5}{|c|}{ Scandals Connected to Jacob Zuma, Guptas, Other Key Networks and ANC Politics } \\
\hline \multicolumn{5}{|c|}{ Investigations concerning Private Sector } \\
\hline $\begin{array}{l}\text { Budlender } \\
\text { report on } \\
\text { Trillian }\end{array}$ & $\begin{array}{l}\text { Released in } \\
\text { June } 2017 .\end{array}$ & $\begin{array}{l}\text { Trillian Holdings Board appointed Geoff } \\
\text { Budlender SC to undertake investigations into } \\
\text { State Capture allegations at Trillian Capital. } \\
\text { Detailed accounts from whistle-blowers } \\
\text { highlighted how information was withheld by } \\
\text { senior management at Trillian. }\end{array}$ & - Trillion & - Eskom \\
\hline $\begin{array}{l}\text { Collapse of } \\
\text { VBS Mutual } \\
\text { Bank }\end{array}$ & $\begin{array}{l}\text { Investigation } \\
\text { launched in } \\
\text { April } 2018 \text { and } \\
\text { the report was } \\
\text { released in } \\
\text { October } 2018 .\end{array}$ & $\begin{array}{l}\text { Minister of Finance placed VBS under } \\
\text { curatorship with effect from } 11 \text { March 2018. In } \\
\text { April 2018, the Deputy Governor of the South } \\
\text { African Reserve Bank instituted an investigation } \\
\text { into VBS. The outcomes of the investigation } \\
\text { showed blatant fraud and corruption by senior } \\
\text { executives/Board and how they extracted } \\
\text { money from the bank. Municipal funds were } \\
\text { illegally deposited with VBS (senior ANC and } \\
\text { EFF politicians have been implicated). }\end{array}$ & $\begin{array}{l}\text { - SARB } \\
\text { investiga- } \\
\text { tion report } \\
\text { VBS Mutual } \\
\text { Bank - The } \\
\text { Great Bank } \\
\text { Heist }\end{array}$ & $\begin{array}{l}\text { - Several } \\
\text { Provincial and } \\
\text { Municipal } \\
\text { Officials } \\
\text { (Limpopo } \\
\text { Government) } \\
\text { - SOEs } \\
\text { (particularly } \\
\text { PRASA) }\end{array}$ \\
\hline $\begin{array}{l}\text { SA Institute } \\
\text { of Chartered } \\
\text { Accountants' } \\
\text { (SAICA) } \\
\text { investigation } \\
\text { into KPMG }\end{array}$ & $\begin{array}{l}\text { Final report was } \\
\text { handed to SAICA in } \\
\text { December } 2018 .\end{array}$ & $\begin{array}{l}\text { SA Institute of Chartered Accountants (SAICA) } \\
\text { established an Inquiry to investigate state } \\
\text { capture related allegations of misconduct of its } \\
\text { members who worked for KPMG. The Inquiry } \\
\text { chaired by advocate Dumisa Ntsebeza held } \\
\text { public hearings and handed its final report to } \\
\text { SAICA in December 2018. Indications are that } \\
\text { the final report will not be made public until all } \\
\text { investigations and disciplinary hearings have } \\
\text { been finalised. }\end{array}$ & - SAICA & - Guptas \\
\hline Bell Pottinger & $\begin{array}{l}2017 \text { investigation } \\
\text { by PRCA. }\end{array}$ & $\begin{array}{l}\text { In 2016, the Guptas appointed British PR } \\
\text { company, Bell Pottinger, who developed and } \\
\text { promoted a campaign that underpinned the RET } \\
\text { and WMC narratives. In 2017, there was an } \\
\text { independent law firm review by Herbert Smith } \\
\text { Freehills resulting in Bell Pottinger's expulsion } \\
\text { from the Public Relations and Communications } \\
\text { Association (PRCA). }\end{array}$ & $\begin{array}{l}\text { - PRCA } \\
\text { - GuptaLeaks } \\
\text { - Ongoing } \\
\text { research } \\
\text { on disinfor- } \\
\text { mation }\end{array}$ & - Guptas \\
\hline
\end{tabular}

